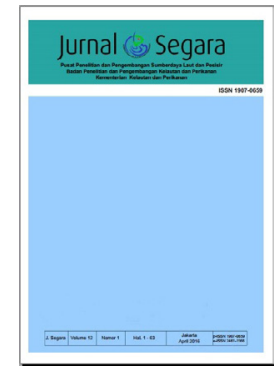

JURNAL SEGARA

http://ejournal-balitbang.kkp.go.id/index.php/segara

ISSN : 1907-0659

e-ISSN : 2461-1166

Nomor Akreditasi: 766/AU3/P2MI-LIPI/10/2016

\title{
ANALISIS KESESUAIAN DAN DAYA DUKUNG PERAIRAN UNTUK PENGEMBANGAN BUDIDAYA RUMPUT LAUT DI KABUPATEN SIMEULUE, ACEH
}

\section{ANALYSIS OF SUITABLE SITE AND CARRYING CAPACITY FOR SEAWEED AQUACULTURE DEVELOPMENT IN SIMEULUE REGENCY, ACEH}

\author{
( Nyoman Radiarta1), Erlania ${ }^{2)}$ \& Joni Haryadi3) \\ 1)Balai Riset dan Observasi Laut \\ Jl. Baru Perancak, Jembrana Bali \\ 2) Pusat Riset Perikanan \\ Jl. Ragunan 20 Pasar Minggu, Jakarta Selatan 12540 \\ 3)Balai Penelitian Pemulihan dan Konservasi Sumber Daya Ikan \\ Jl. Cilalawi No.1, Jatiluhur, Kec. Purwakarta, Jawa Barat
}

Diterima : 5 Juni 2017 ; Selesai Perbaikan : 8 Maret 2018 ; Disetujui Setelah Perbaikan: 23 Maret 2018

\begin{abstract}
ABSTRAK
Rumput laut merupakan salah satu primadona produksi perikanan budi daya di Indonesia. Ektensifikasi lokasi budi daya rumput laut telah menyebar sampai ke pulau-pulau terdepan Indonesia. Perluasan kawasan ini harus didukung oleh ketersediaan data dan informasi yang akurat tentang kesesuaian perairan lokasi budi daya. Penelitian ini bertujuan untuk melakukan analisis spasial kesesuaian dan daya dukung perairan untuk pengembangan budi daya rumput laut di Kabupaten Simeulue, Aceh. Penelitian dilaksanakan pada Agustus 2015, dan berlokasi di tiga teluk besar yaitu Teluk Sibigo, Teluk Dalam, dan Teluk Sinabang. Analisis spasial kesesuaian lahan dilakukan dengan sistem informasi geografis berdasarkan multi criteria evaluation dengan menggabungkan tiga submodel yaitu fisik dan geografi, kualitas air, dan sosial infrastruktur. Daya dukung kawasan dihitung dengan pendekatan kapasitas unit budi daya di perairan tersebut. Hasil analisis menunjukkan bahwa ketiga teluk memiliki potensi pengembangan dengan luasan yang bervariasi: 159 ha (Teluk Sibigo), 808 ha (Teluk Dalam), dan 684 ha (Teluk Sinabang). Perhitungan daya dukung menunjukkan bahwa Teluk Dalam mempunyai kapasitas yang terluas yaitu 494,7 ha. Pemanfaatan kawasan secara maksimal dapat mencapai produksi berkisar antara 723-3030 ton/siklus tanam. Kesesuaian lahan (zonasi) dan daya dukung perairan yang dihasilkan dalam penelitian ini dapat dijadikan landasan penting mendukung penerapan budi daya perikanan yang berbasis ekosistem.
\end{abstract}

Keywords: Analisis spasial, rumput laut, kesesuaian perairan, daya dukung, Kabupaten Simeulue.

\begin{abstract}
Seaweed is one of the promising aquaculture productions in Indonesia. The seaweed culture has widely developed to the outer islands of Indonesia. Therefore, the development of the seaweed culture should be followed by the availability of accurate data and the information on suitable sites. The objective of this study was to conduct spatial analysis of site suitability and carrying capacity for the development of seaweed aquaculture in Simeulue Regency, Aceh. The study was conducted on August 2015, and located at three large bays namely the Sibigo Bay, Dalam Bay, and Sinabang Bay. Site suitability was spatially analyzed with a geographical information system based on multi-criteria evaluation by combining three submodels: physical and geography, water quality, and social infrastructure. The carrying capacity of the area was based on the capacity of seaweeds unit in the study sites. The results indicated that suitable sites for three bays extent were 159 ha (Sibigo Bay), 808 ha (Dalam Bay), and 684 ha (Sinabang Bay). Carrying capacity calculations indicate that Dalam Bay had the highest capacity of about 494.7 ha. The maximum utilization of those potential area can reach production ranging between 723-3030 ton/cycle.
\end{abstract}

Corresponding author:

Jl. Pasir Putih I Ancol Timur, Jakarta Utara 14430. Email: radiarta@gmail.com 
Suitable site (zoning) and the carrying capacity of water obtained from this study should become an important aspect to support the implementation of ecosystem approach to aquaculture (EAA).

Keywords: Spatial analysis, seaweeds, suitable sites, carrying capacity, Simeulue Regency.

\section{PENDAHULUAN}

Potensi kelautan dan perikanan di Kabupaten Simeulue cukup besar. Terdapat lima teluk luas yang sangat potensial bagi usaha budi daya laut, yaitu Teluk Sinabang, Teluk Dalam, Teluk Sibigo, Teluk Lewak, dan Teluk Alafan. Aktivitas budi daya laut yang berpotensi untuk dikembangkan meliputi budi daya laut menggunakan Keramba Jaring Apung (KJA) dengan komoditas potensial seperti kerapu, lobster, dan teripang; serta budi daya tiram mutiara, rumput laut, dan kekerangan lainnya menggunakan sistem long-line. Melihat potensi yang besar ini, Kabupaten Simeulue dijadikan sebagai salah satu dari lima kawasan golden ring yang dikembangkan sebagai Pusat Pengembangan Kawasan Kelautan dan Perikanan Terintegrasi (PK2PT). Empat kawasan golden ring yang lain adalah Anambas, Kepulauan Riau; Tahuna, Sulawesi Utara; Saumlaki, Maluku; dan Merauke, Papua (Anonimous, 2015).

Pengembangan perikanan budi daya termasuk budi daya laut (marikultur) harus dilakukan secara komprehensif dengan memperhatikan lima aspek penting, yaitu (1) dampak lingkungan, (2) keamanan sistem (biosecurity), (3) dampak dan keuntungan sosial ekonomi, (4) kualitas dan keamanan makanan, dan (5) perhatian terhadap binatang (animal welfare) (Perera, 2013). Dari kelima aspek tersebut, tahapan pengembangan marikultur harus memperhatikan tiga tahapan penting yaitu (1) perencanaan yang meliputi kesesuaian dan potensi lahan, (2) pelaksanaan budi daya yang meliputi input dalam sistem budi daya, dan (3) pasca panen yang meliputi transportasi, pengolahan, dan pemasaran ke konsumen. Dengan memperhatikan tiga tahapan yang didukung oleh lima aspek penting tersebut, diharapan pengembangan marikultur dapat sesuai dengan kaidah Ecosystem Approach to Aquaculture (EAA), sehingga pelaksanaannya dapat berkelanjutan dan berwawasan lingkungan (Soto et al., 2008).

Rumput laut merupakan komoditas penting kelautan dan perikanan Indonesia. Budi daya rumput laut di Indonesia lebih difokuskan pada produksi jenis Kappaphycus dan Eucheuma sebagai penghasil karaginan. Produksi budi daya rumput laut menunjukkan peningkatan yang sangat signifikan selama satu dekade yaitu < 450 ribu ton pada 2004 menjadi sekitar 10 juta ton pada 2014 (FAO, 2016). Produksi rumput laut tersebut masih dapat ditingkatkan, karena peluang pemanfaatan kawasan yang dimiliki masih sangat besar yaitu sekitar 11,7 juta ha (KKP, 2014). Dalam pengembangan kawasan tersebut tahapan awal yang perlu dilakukan adalah kajian kesesuaian perairan dengan mempertimbangkan beberapa aspek penting diantaranya kondisi lingkungan pesisir, kualitas perairan (fisik, kimia, dan biologi), sosial ekonomi, infrastruktur penunjang, dan peraturan daerah yang ada. Kajian ini dapat dilakukan secara spasial sehingga dapat memberikan hasil analisis yang komprehensifdengan mempertimbangkan aspek-aspek penting dalam kesesuaian perairan (Ross et al., 2013).

Analisis spasial dengan Sistem Informasi Geografis (SIG) telah banyak digunakan dalam kajian kesesuaian perairan dan daya dukung kawasan baik di perairan tawar maupun laut (Ross et al., 2011; de Sousa et al., 2012). Ross et al. (2013) secara komprehensif memberikan penjelasan tentang analisis kesesuaian lahan dan daya dukung kawasan dibidang perikanan budi daya. Analisis kesesuaian lahan merupakan tahapan penting dalam penyusunan perencanaan spasial kawasan pesisir, sehingga terjadi sinergitas antara aktivitas yang berkembang di kawasan pesisir (Sanchez-Jerez et al., 2016).

Penelitian ini bertujuan untuk melakukan analisis spasial kesesuaian perairan dan menghitung daya dukung perairan untuk pengembangan budi daya rumput laut di Kabupaten Simeulue, Aceh. Analisis spasial dilakukan berdasarkan teknik spasial Multi Ceriteria Evaluation (MCE) dengan menggunakan SIG.

\section{METODE PENELITIAN}

\section{Lokasi penelitian}

Penelitian telah dilaksanakan di Kabupaten Simeulue Provinsi Aceh (Gambar 1), yang meliputi tiga teluk besar yaitu Teluk Sibigo ( $2^{\circ} 51^{\prime} \mathrm{LU}$; $95^{\circ} 54^{\prime} \mathrm{BT}$ ), Teluk Dalam ( $2^{\circ} 40^{\prime} \mathrm{LU} ; 96^{\circ} 8^{\prime} \mathrm{BT}$ ), dan Teluk Sinabang ( $2^{\circ} 30^{\prime} \mathrm{LU}$; $\left.96^{\circ} 24^{\prime} \mathrm{BT}\right)$. Ketiga teluk ini memiliki karakteristik kawasan yang cukup berbeda. Teluk Sibigo (Kecamatan Simeulue Timur) dan Teluk Dalam (Kecamatan Teluk Dalam) merupakan teluk yang semi tertutup. Aktivitas budi daya laut telah berkembang di Teluk Dalam berupa budi daya ikan dan penampungan lobster. Teluk Sinabang terletak di Kecamatan Simeulue Timur yang merupakan ibukota Kabupaten Simeulue. Berbagai aktivitas ditemukan di pesisir Teluk Sinabang meliputi: pelabuhan kapal, kawasan industri, penangkapan ikan, dan budi daya laut. Ketiga teluk ini memiliki potensi yang sangat besar untuk pengembangan budi daya laut di Kabupaten Simeulue. 


\section{Pengumpulan data}

Pengumpulan data kondisi perairan dilaksanakan pada Agustus 2015. Sebanyak 170 titik pengamatan kualitas air berhasil dikumpulkan (Gambar 1), dengan rincian masing-masing: 38 stasiun (Teluk Sibigo), 69 stasiun (Teluk Dalam), dan 63 stasiun (Teluk Sinabang). Sebaran titik pengamatan kualitas perairan dirancang dengan SIG yang disebar secara acak sistimatis (systematic random sampling). Kondisi kawasan perairan dan pesisir menjadi pertimbangan dalam menentukan titik pengamatan di masing-masing teluk. Pengumpulan data kualitas air dilakukan melalui pengukuran langsung di lapangan (insitu) dan pengamatan di laboratorium (eksitu). Pengukuran kualitas perairan insitu meliputi parameter suhu, salinitas, kekeruhan, $\mathrm{pH}$, oksigen terlarut (DO), kecerahan, kedalaman, dan kecepatan arus. Sedangkan parameter yang dianalisis di laboratorium meliputi amonia $\left(\mathrm{NH}_{3}-\mathrm{N}\right)$, nitrat $\left(\mathrm{NO}_{3}-\mathrm{N}\right)$, dan fosfat $\left(\mathrm{PO}_{4}^{-} \mathrm{P}\right)$. Data yang dikumpulkan dari Teluk Sinabang meliputi suhu, $\mathrm{pH}$, nitrat $\left(\mathrm{NO}_{3}{ }^{-} \mathrm{N}\right)$, dan fosfat $\left(\mathrm{PO}_{4}^{-} \mathrm{P}\right)$ dalam penelitian ini mengacu pada Erlania et al. (2017). Analisis air ini dilakukan di Laboratorium Proling Fakultas Perikanan dan IImu Kelautan IPB, Bogor. Pengambilan, preservasi, dan analisis contoh air pada penelitian ini mengacu pada metode standar APHA
(2012). Selain pengukuran di dekat permukaan, pengukuran secara stratifikasi vertikal juga dilakukan dibeberapa titik pengamatan untuk parameter suhu dan salinitas (Gambar 1).

Peta dasar yang digunakan dalam analisis spasial diperoleh dari Badan Informasi Geospasial (BIG) berupa peta Rupa Bumi Indonesia (RBI) dengan skala 1:50.000. Tema dasar yang dikumpulkan meliputi: hidrografi (sungai, danau, dan garis pantai), tutupan lahan (hutan, sawah, dan pemukiman), data ketinggian, transportasi, batas administrasi, dan toponimi.

\section{Analisis spasial}

Parameter yang terkumpul dianalisis secara spasial yang ditampilkan dalam bentuk sebaran vertikal dan horisontal. Analisis sebaran vertikal parameter kualitas air (suhu dan salinitas) menggunakan teknik weighted average gridding yang terdapat dalam perangkat Ocean Data View (ODV) (Schlitzer, 2011). Sebaran spasial horisontal parameter lainnya (lingkungan, kualitas air, dan sosial infrastruktur) dianalisis dengan teknik interpolasi yang terdapat dalam perangkat lunakArcGIS v.10 (The Environmental System Research Institute (ESRI), USA).

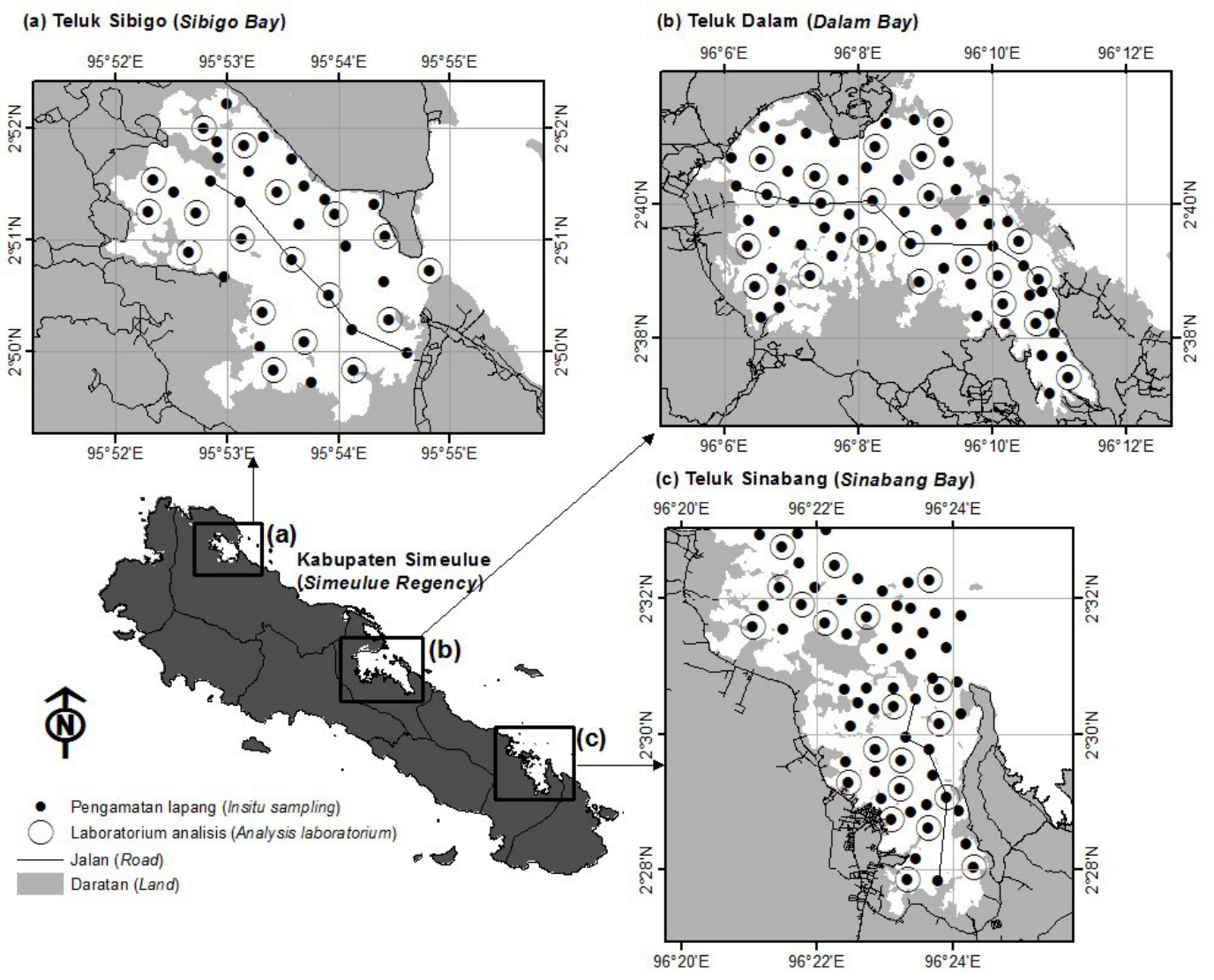

Gambar 1. Lokasi penelitian di Teluk Sibigo (a), Teluk Dalam (b), dan Teluk Sinabang (c) Kabupaten Simeulue, Aceh, dan distribusi titik pengamatan kualitas perairan. Garis yang menghubungkan antar titik merupakan stasiun pengamatan vertikal. 


\section{Analisis kesesuaian perairan}

Analisis kesesuaian untuk budi daya rumput laut dalam penelitian ini menggunakan teknik spasial MCE (Malczewski, 1999; Nath et al., 2000; de Sousa et al., 2012). Sebanyak 14 parameter digunakan dalam analisis kesesuaian perairan. Seluruh parameter tersebut kemudian dikelompokkan kedalam tiga submodel yaitu submodel fisik dan geografi (keterlindungan, kedalaman, dan kecepatan arus), submodel kualitas air (suhu, salinitas, kecerahan, kekeruhan, $\mathrm{pH}$, amonia, nitrat, dan fosfat), dan submodel sosial infrastruktur (jarak ke pemukiman, jarak ke sungai, dan jarak ke pelabuhan). Ketiga submodel ini disusun dalam bentuk hirarki (Malczewski, 2000), dengan tujuan untuk menghasilkan model kesesuaian perairan untuk budi daya rumput laut di Kabupaten Simeulue. Bagian utama hirarki adalah keluaran akhir (goal), kemudian terbagi menjadi bagian yang lebih komplek meliputi submodel dan parameter (Gambar 2).

Tingkat kesesuaian dari masing-masing parameter yang digunakan dalam penelitian ini disusun dalam kisaran nilai penting (skor). Sistem skor 1-4 telah digunakan dalam penelitian ini (Tabel 1), dimana 1 adalah skor dengan kategori tidak sesuai dan 4 adalah sangat sesuai (Giap et al., 2005; Radiarta et al., 2014). Pembagian skor tingkat kesesuaian untuk masing-masing parameter mengacu pada Tiensongrusmee (1990), Mubarak et al. (1990), Sulistijo \& Nontji (1995), KLH (2004), Radiarta et al. (2008), dan Parenrengi et al. (2011).
Penentuan bobot berdasarkan tingkat kepentingan parameter dalam mempengaruhi kesesuaian budi daya rumput laut di lokasi penelitian. Bobot ditentukan dengan pair-wise comparison, yang dikenal dengan metode analytical hierarchy process (AHP; Banai-Kashani, 1989). Berdasarkan kondisi lapangan, tingkat kepentingan, dan opini peneliti (expert judment), maka bobot yang diberikan pada masing-masing parameter dan submodel cukup bervariasi seperti terlihat pada Gambar 2. Bobot submodel fisik dan geografi memiliki bobot terbesar, hal ini disebabkan karena kedalaman merupakan salah satu faktor pembatas pengembangan budi daya rumput laut di lokasi penelitian. Sedangkan parameter lain umumnya dalam kondisi yang baik dan mendukung pengembangan budi daya rumput laut.

Berdasarkan nilai skor dan bobot yang telah ditentukan, maka langkah selanjutnya adalah analisis spasial kesesuaian perairan. Analisis ini menggunakan metode weighted linear combination, yang merupakan aplikasi dari multi-ceriteria evaluation (Malczewski, 1999). Tahapan ini dilakukan dengan dengan pemodelan yang terdapat dalam perangkat lunak ArcGIS versi 10.3 .

\section{Analisis daya dukung perairan}

Analisis daya dukung perairan untuk budi daya rumput laut di Kabupaten Simeulue dilakukan melalui pendekatan kapasitas perairan. Penjelasan secara rinci tentang pendekatan daya dukung ini mengacu pada Azis (2011) dan Erlania \& Radiarta (2014). Secara

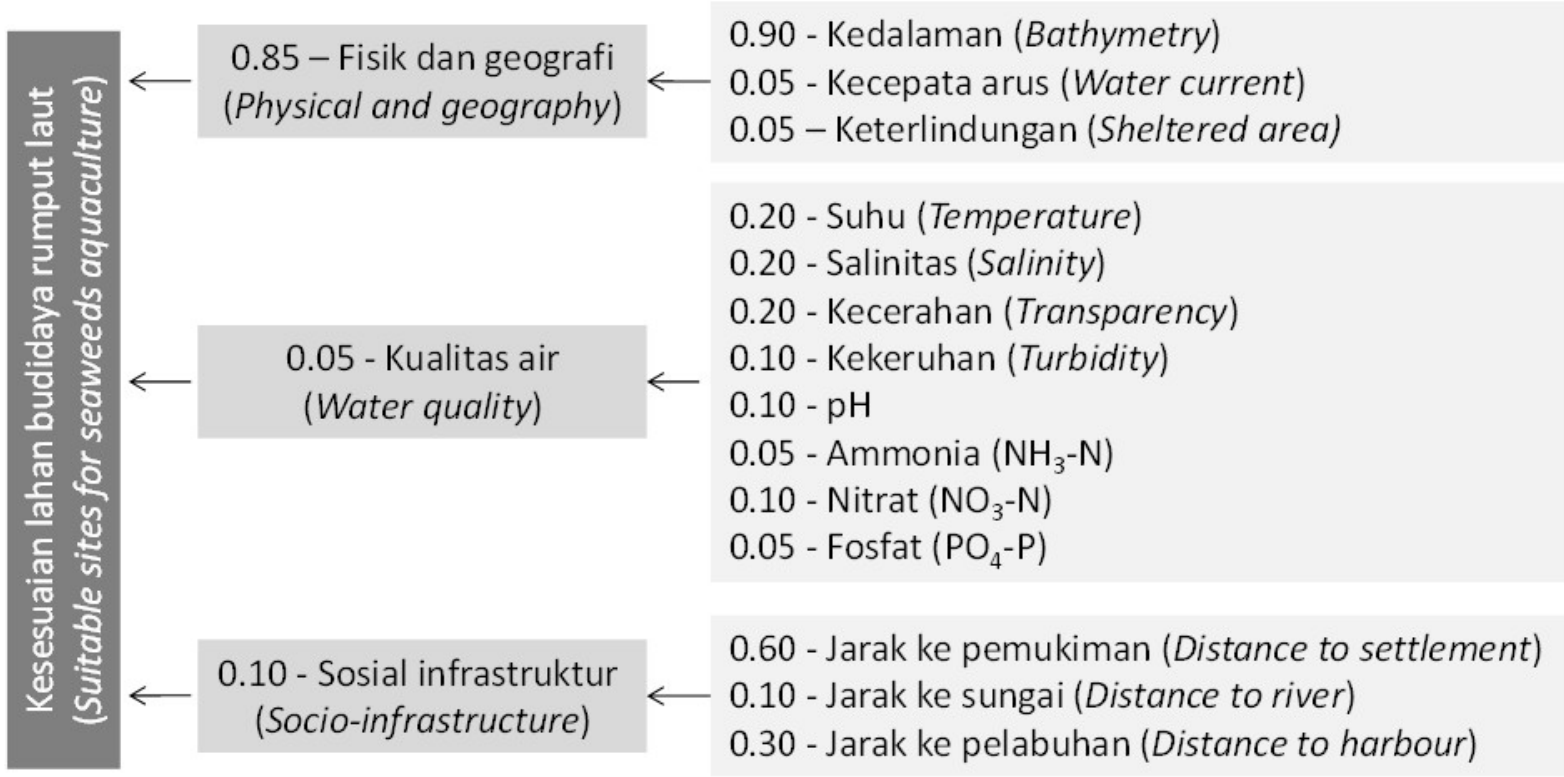

Gambar 2. Model hirarki kesesuaian perairan untuk budidaya rumput laut di Kabupaten Simeulue, Aceh. Angka menunjukkan bobot yang digunakan. 
Table 1.

Kisaran nilai masing-masing parameter untuk kesesuaian budi daya rumput laut dengan metode longline di Kabupaten Simeulue, Aceh

\begin{tabular}{|c|c|c|c|c|c|}
\hline \multirow[b]{2}{*}{ Peubah } & \multicolumn{4}{|c|}{ Kisaran nilai berdasarkan tingkat kesesuain } & \multirow[b]{2}{*}{$\begin{array}{l}\text { Tidak sesuai } \\
\text { (1) }\end{array}$} \\
\hline & Satuan & $\begin{array}{l}\text { Sangat sesuai } \\
\text { (4) }\end{array}$ & $\begin{array}{l}\text { Sesuai } \\
\text { (3) }\end{array}$ & $\begin{array}{l}\text { Cukup sesuai } \\
\text { (2) }\end{array}$ & \\
\hline \multicolumn{6}{|l|}{ Fisik dan geografi } \\
\hline Keterlindungan & & Tertutup & $\begin{array}{l}\text { Cukup } \\
\text { tertutup }\end{array}$ & $\begin{array}{l}\text { Tertutup } \\
\text { sementara }\end{array}$ & Terbuka \\
\hline Kedalaman & $\mathrm{m}$ & $3-10$ & $10-15$ & $15-20$ & $<3$ and $>20$ \\
\hline Kecepatan arus & $\mathrm{cm} / \mathrm{s}$ & $10-30$ & $0-40$ & $40-50$ & $<10$ and $>50$ \\
\hline \multicolumn{6}{|l|}{ Kualitas air } \\
\hline kecerahan & $\mathrm{m}$ & $>3$ & $2--3$ & $1--2$ & $<1$ \\
\hline Suhu & ${ }^{\circ} \mathrm{C}$ & $28-32$ & $32-35 ; 27-28$ & $35-37$ & $<27 ;>37$ \\
\hline Salinitas & ppt & $30-34$ & $28-30$ & $25-28$ & $<25$ and $>34$ \\
\hline $\mathrm{pH}$ & $\mathrm{mg} / \mathrm{L}$ & $7,5-8,5$ & $4-7,5 ; 8,5-10$ & $2-4 ; 10-11$ & $<2 ;>11$ \\
\hline Kekeruhan & NTU & $<10$ & $10-20$ & $20-30$ & $>30$ \\
\hline Ammonia $\left(\mathrm{NH}_{3}{ }^{-} \mathrm{N}\right)$ & $\mathrm{mg} / \mathrm{l}$ & $>0,1$ & $0,01-0,1$ & $0,001-0,01$ & $<0,001$ \\
\hline Nitrat $\left(\mathrm{NO}_{3}-\mathrm{N}\right)^{3}$ & $\mathrm{mg} / \mathrm{l}$ & $>0,1$ & $0,01-0,1$ & $0,001-0,01$ & $<0,001$ \\
\hline Phosphat $\left(\mathrm{PO}_{4}^{-} \mathrm{P}\right)$ & $\mathrm{mg} / \mathrm{l}$ & $>0,1$ & $0,01-0,1$ & $0,001-0,01$ & $<0,001$ \\
\hline \multicolumn{6}{|l|}{ Sosial-infrastruktur } \\
\hline Jarak ke pemukiman & $\mathrm{km}$ & $<3$ & $3-4$ & $4-5$ & $>5$ \\
\hline Jarak ke sungai & $\mathrm{km}$ & $>1,00$ & $0,75-1,00$ & $0,50-0,75$ & $<0,50$ \\
\hline Jarak ke pelabuhan & $\mathrm{km}$ & $>1,50$ & $1,00-1,50$ & $0,75-1,00$ & $<0,75$ \\
\hline
\end{tabular}

singkat tahapan yang dilakukan adalah:

1. Menentukan tingkat kesesuaian budi daya rumput laut. Pada penelitian ini tingkat kesesuaian dengan kategori sangat sesuai dan sesuai yang dipakai dalam melakukan analisis daya dukung kawasan.

2. Menghitung kapasitas perairan. Perhitungan ini berdasarkan unit budi daya yang digunakan di lokasi penelitian. Pada penelitian ini menggunakan unit standar budi daya rumput laut yang dikeluarkan oleh Direktorat Jenderal Perikanan Budi daya yaitu 50 m x 50 m (BBL Lombok, 2012).

3. Menentukan luasan ideal unit budi daya rumput laut. Luas ideal unit budi daya diperoleh dengan menambahkan $10 \mathrm{~m}$ pada setiap sisi dari satu unit budi daya. Sehingga luas ideal diperoleh adalah: $70 \mathrm{~m}$ $x 70 \mathrm{~m}=4.900 \mathrm{~m}^{2}=0,49$ ha .

4. Menghitung daya dukung kawasan = luas perairan yang sesuai (ha) $x$ kapasitas perairan $(\%)$

\section{HASIL DAN PEMBAHASAN}

Berdasarkan pedoman rencana tata ruang wilayah dan rencana program pemerintah daerah, maka pengembangan perikanan budi daya diarahkan ke Kecamatan Simeulue Barat (Teluk Sibigo) dan Kecamatan Teluk Dalam. Sedangkan Kecamatan
Simelue Timur khususnya kawasan pelabuhan perikanan Sinabang di Lugu dan sekitarnya ditetapkan sebagai kawasan pusat pengembangan kelautan dan perikanan terintegrasi, termasuk produksi budi daya perikanan (Anonimous, 2015). Sementara Balai Benih Ikan Pantai (BBIP) Simeulue yang terletak di Desa Busung Kecamatan Teupah Tengah berfungsi sebagai pusat pengembangan pembenihan dan hatchery ikan laut yang akan mendukung percepatan pengembangan marikultur di tiga kawasan tersebut. Aktivitas perbenihan yang telah dilakukan oleh BBIP antara lain pembenihan ikan kerapu macan, kerapu bebek, ikan hias clownfish, ikan kakap putih, dan kakap merah. Selain itu, BBIP juga telah mampu mengembangkan jenis pakan alami seperti rotifera dan mikroalga.

\section{Kondisi vertikal kualitas air}

Pengukuran parameter kualitas air secara vertikal (0-15 m) dilakukan di beberapa titik yang berlokasi di tengah kawasan teluk yaitu Teluk Sibigo, Teluk Dalam dan Teluk Sinabang (Gambar 3). Kondisi suhu perairan di ketiga teluk memiliki karakteristik yang relatif sama yaitu hangat di permukaan dan suhu mengalami penurunan seiring dengan bertambahnya kedalaman perairan. Kisaran suhu di masing-masing lokasi adalah $29,52-30,60^{\circ} \mathrm{C}$ (Teluk Sibigo), $28,53-31,51^{\circ} \mathrm{C}$ (Teluk Dalam), dan $29,85-31,09^{\circ} \mathrm{C}$ (Teluk Sinabang). Kondisi suhu ini secara umum masih sangat sesuai untuk pengembangan budi daya rumput laut dengan 

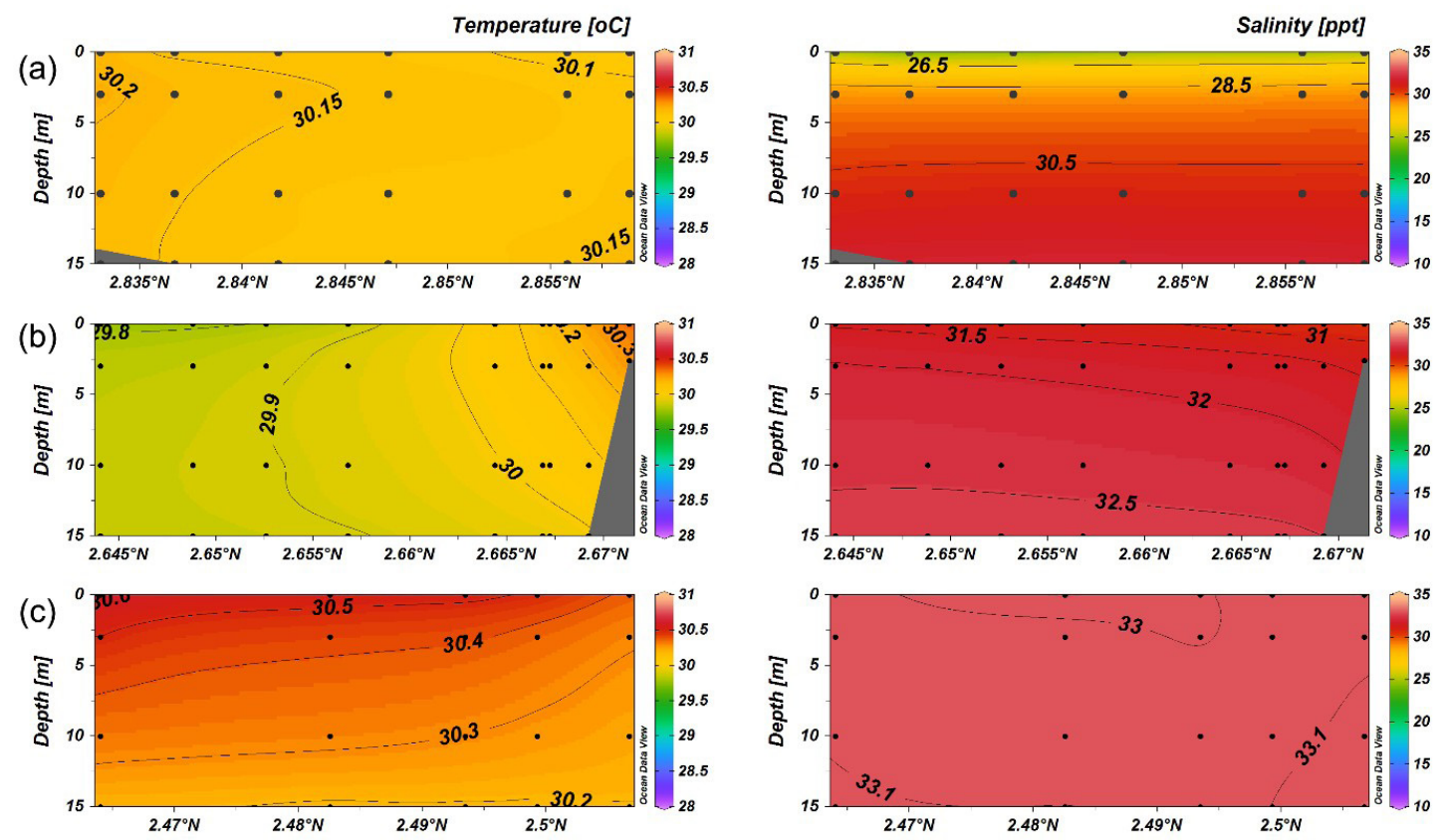

Gambar 3. Sebaran vertikal suhu dan salinitas di Teluk Sibigo (a) Teluk Dalam (b), dan Teluk Sinabang (c) Kabupaten Simeulue, Aceh. Lokasi titik pengamatan dapat dilihat pada Gambar 1.

metode longline. Suhu ideal untuk budi daya rumput laut adalah sekitar $25-30^{\circ} \mathrm{C}$ (Tiensongrusmee, 1990; Mubarak et al., 1990).

Distribusi salinitas secara stratifikasi vertikal menunjukkan nilai yang sangat berbeda antara tiga teluk, terutama di Teluk Sibigo. Pada permukaan perairan Teluk Sibigo memiliki nilai salinitas yang sangat rendah yaitu 13,2 ppt (Gambar 3), makin ke dalam nilai salinitas semakin tinggi. Beberapa faktor yang menyebabkan rendahnya salinitas di permukaan adalah banyaknya air tawar yang masuk ke dalam teluk, dan dengan mulut teluk yang kecil menyebabkan pertukaraan air menjadi lambat, sehingga lapisan air tawar cukup lama bisa bertahan di kawasan ini. Kecenderungan salinitas lebih tinggi di dasar perairan juga dipengaruhi oleh suhu perairan yang rendah sehingga kelarutan garam-garam mineral di dasar perairan lebih tinggi (Effendi, 2003). Kondisi salinitas permukaan perairan yang rendah ini sangat mempengaruhi pertumbuhan rumput laut, yang dapat menyebabkan timbulnya penyakit. Salinitas yang ideal untuk budi daya rumput laut adalah sekitar 28-35 ppt (Parenrengi et al., 2011). Kondisi salinitas di dua teluk lainnya umumnya berada pada kisaran yang baik yaitu 25,60-33,60 ppt (Teluk Dalam) dan 32,20-33,50 ppt (Teluk Sinabang).

Berdasarkan survai lapangan pada tiga kawasan perairan potensial di Kabupaten Simeulue, yaitu Teluk Sinabang, Teluk Dalam, dan Teluk Sibigo diperoleh berbagai informasi mengenai gambaran aktivitas budi daya laut yang telah berkembang pada masing-masing lokasi. Dari ketiga kawasan perairan tersebut, kegiatan budi daya laut hanya berkembang di kawasan Teluk Dalam dan Teluk Sinabang, sedangkan di Teluk Sibigo sudah tidak ditemukan adanya aktivitas budi daya laut. Bentuk aktivitas budi daya laut yang berkembang di Teluk Dalam dan Teluk Sinabang berupa budi daya ikan dengan Keramba Jaring Apung (KJA), dengan jenis ikan yang dibudi dayakan antara lain ikan kerapu, kakap putih, kue, dan napoleon, serta lobster. Tidak berkembangnnya kegiatan budi daya laut di Teluk Sibigo disebabkan karena kondisi perairan yang kurang mendukung. Dari hasil pengukuran kondisi kualitas air secara vertikal, terlihat bahwa perairan tersebut banyak menerima masukan air tawar dari sungai-sungai yang bermuara pada kawasan teluk sehingga salinitas permukaan sangat rendah (Gambar 3). Masukan air tawar tersebut berlangsung hampir setiap hari, terutama pada waktu musim hujan.

\section{Kesesuaian budi daya rumput laut}

Kesesuaian perairan untuk budi daya laut merupakan bagian yang tak terpisahkan dengan perencanaan spasial (spatial planning) suatu kawasan pengembangan. Pada dasarnya, perencanaan spasial perikanan budi daya berkontribusi terhadap proses pemilihan lokasi yang cocok untuk aktivitas budi daya, ketika aktivitas ini terintegrasi dengan perencanaan kedepan sehubungan dengan regulasi, manajemen, dan konservasi lingkungan laut; pemilihan lokasi tersebut harus mempertimbangkan beberapa faktor secara kumulatif (fisik/geografi, kondisi perairan, sosial, infrastruktur, ekonomi, dan pemanfaatan lahan lainnya), sehingga analisis yang dihasilkan sesuai dengan pendekatan perikanan budi daya berbasis ekosistem 
(Soto et al., 2008; Ross et al., 2013).

Penentuan kesesuaian perairan untuk budi daya laut tidak hanya berpatokan pada kondisi kualitas air, namun kondisi fisik/geografi kawasan dan sosial infrastruktur juga harus diperhatikan secara seksama (Radiarta et al., 2011; Ross et al., 2013). Penggabungan ketiga faktor tersebut akan memberikan hasil analisis yang komprehensif. Dalam penelitian ini ketiga faktor tersebut telah dipertimbangkan dalam melakukan analisis kesesuaian budi daya rumput laut, dan telah memberikan nilai kuantitatif luasan perairan untuk pengembangan budi daya rumput laut sesuai dengan tingkat kesesuaian lahan (Tabel 2). Peta kesesuaian perairan untuk budi daya rumput laut berdasarkan submodel fisik dan geografi, kualitas air, dan sosial infrastruktur ditampilkan pada Gambar 4.

Fisik dan geografi perairan di lokasi penelitian dianalisis dengan mempertimbangkan tiga parameter penting yaitu keterlindungan, kedalaman, dan kecepatan arus. Secara umum tiga teluk lokasi penelitian termasuk dalam kategori terlindung, terutama untuk Teluk Sibigo dan Teluk Dalam (Gambar 1). Kondisi ini memberikan keleluasaan dalam pemilihan lokasi pengembangan budi daya rumput laut di lokasi penelitian. Berdasarkan kedalaman perairan ketiga teluk menunjukkan karakteristik yang unik. Daerah yang relatif dangkal dan sesuai untuk budi daya rumput laut hanya berada pada beberapa meter dari pesisir pantai, setelah itu kedalaman perairan sudah tidak sesuai lagi (Gambar 4). Kondisi ini menjadikan parameter kedalaman perairan merupakan faktor pembatas pengembangan budi daya rumput laut di lokasi penelitian. Untuk budi daya rumput laut menggunakan metode longline (rawai), kedalaman perairan yang ideal adalah sekitar 2-15 m (Parenrengi et al., 2011). Arus merupakan parameter penting untuk budi daya rumput laut, karena berperan untuk menyebarkan nutrien yang baru, merangsang pertumbuhan rumput laut, menjaga stabilitas suhu perairan, serta dapat membersihkan tanaman. Hasil pengamatan kondisi arus perairan di tiga teluk (rataan kecepatan arus $0,2 \pm 0,12 \mathrm{~m} /$ detik) menunjukkan kisaran yang baik untuk budi daya rumput laut. Menurut Tiensongrusmee (1990), kecepatan arus ideal adalah sebesar $0,2 \mathrm{~m} /$ detik; namun jika kandungan nutrien pada kawasan tersebut cukup tinggi maka kecepatan arus sekitar 0,1 $\mathrm{m} /$ detik dapat diterima. Berdasarkan faktor lingkungan, kategori sangat sesuai masing-masing sebesar 159 ha (Teluk Sibigo), 808 ha (Teluk Dalam), dan 684 ha (Teluk Sinabang) (Tabel 2).

Kondisi kualitas perairan di lokasi penelitian dapat mempengaruhi pertumbuhan rumput laut, dan secara otomatis berpengaruh terhadap analisis kesesuaian untuk budi daya. Parameter suhu, salinitas, kecerahan, $\mathrm{pH}$, kekeruhan, amonia, nitrat, dan fosfat telah digunakan dalam penelitian ini untuk melihat tingkat kesesuaian perairan berdasarkan submodel kualitas air. Hasil analisis kesesuaian berdasarkan submodel kualitas air menunjukkan bahwa Teluk Dalam dan Teluk Sinabang sangat mendukung untuk budi daya rumput laut dengan kategori sangat sesuai ditemukan masing-masing 2.538 ha dan 2.088 ha (Tabel 2; Gambar 4). Sedangkan Teluk Sibigo menunjukkan tingkat kesesuaian yang lebih rendah, dimana kategori yang ditemukan hanya sesuai dan cukup sesuai dengan luasan masing-masing 1.102 ha dan 359 ha (Tabel 2). Parameter nutrien sangat

Table 2.

Luasan perairan berdasarkan tingkat kesesuaian perairan untuk budidaya rumput laut di Kabupaten Simeulue, Aceh. Luasan potensial Teluk Sibigo: 1.461 ha, Teluk Dalam: 4.231 ha, dan Teluk Sinabang: 2.221 ha

\begin{tabular}{lllll}
\hline \multirow{2}{*}{ Parameter } & \multicolumn{4}{c}{ Luasan berdasarkan tingkat kesesuaian (ha) } \\
\cline { 2 - 5 } & Sangat sesuai & Sesuai & Cukup sesuai & Tidak sesuai \\
\hline Teluk Sibigo & & & & \\
Fisik dan geografi & 159 & 82 & 107 & 1.113 \\
Kualitas air & 0 & 1.102 & 359 & 0 \\
Sosial infrastruktur & 1.152 & 309 & 0 & 0 \\
Kesesuaian rumput laut & 159 & 82 & 107 & 1.113 \\
\hline Teluk Dalam & & & & \\
Fisik dan geografi & 808 & 202 & 212 & 3.009 \\
Kualitas air & 2.538 & 1.680 & 13 & 0 \\
Sosial infrastruktur & 2708 & 1.434 & 89 & 3.009 \\
Kesesuaian rumput laut & 808 & 202 & 212 & \\
\hline Teluk Sinabang & & & & 1.036 \\
Fisik dan geografi & 684 & 231 & 270 & 0 \\
Kualitas air & 2.088 & 133 & 0 & 0 \\
Sosial infrastruktur & 1.470 & 751 & 0 & 1.036 \\
Kesesuaian rumput laut & 684 & 231 & 270 & \\
\hline
\end{tabular}


penting diperhatikan dalam menganalisis kesesuaian perairan. Nutrien yang dipertimbangkan dalam analisis kesesuaian perairan di penelitian ini adalah amonia, nitrat, dan fosfat. Ketiga parameter ini memiliki nilai yang cukup baik di lokasi penelitian, dengan nilai rataan masing-masing $0,11 \pm 0,05 \mathrm{mg} / \mathrm{L}, 0,1 \pm 0,04 \mathrm{mg} / \mathrm{L}$, dan 0,02 $\pm 0,01 \mathrm{mg} / \mathrm{L}$. Liu et al. (2013) telah melakukan penajaman hasil analisis kesesuaian budi daya rumput laut Saccharina japonica dari hasil sebelumnya oleh Radiarta et al. (2011) melalui penambahan parameter nitrogen permukaan (SSN: Sea Surface Nitrogen), dan menunjukkan hasil yang lebih baik terutama pada kawasan dengan ketegori sangat sesuai. Hal ini dibuktikan setelah divalidasi dengan kondisi lapangan.

Submodel sosial infrastruktur yang dianalisis dalam penelitian ini meliputi jarak ke pemukiman, jarak ke sungai, dan jarak ke pelabuhan. Ketiga paremeter ini dipilih karena dapat menunjang atau mempengaruhi aktivitas budi daya rumput laut dalam hal ketersediaan tenaga kerja, pengaruh pasokan air tawar dan ketersediaan nutrien dari daratan, serta aktivitas pelayaran. Parameter yang sama juga telah digunakan oleh Radiarta et al. (2011) dan de Sousa et al. (2012) untuk analisis kesesuaian budi daya rumput laut di Jepang dan Brazil. Secara umum ketersediaan fasilitas pendukung untuk pengembangan budi daya rumput laut di tiga teluk menunjukkan kondisi yang baik. Hal ini ditunjukkan dari hasil analisis spasial kesesuaian perairan di lokasi penelitian menghasilkan kategori sangat sesuai dan sesuai (Tabel 2; Gambar
4). Luasan perairan dengan kategori sangat sesuai diperoleh masing-masing 1.152 ha (Teluk Sibigo), 2708 ha (Teluk Dalam), dan 1.470 ha (Teluk Sinabang). Data sosial infrastruktur saja dapat juga dijadikan dasar dalam analisis kesesuaian budi daya rumput laut, seperti yang dihasilkan oleh de Saousa et al. (2012) yang melakukan penelitian di Rio Grande do Norte, Brazil. Parameter yang dipertimbangkan dalam analisis tersebut meliputi: jarak ke pantai, jarak ke pasar, jarak ke kota kabupaten, jarak ke jalan, jarak ke kota provinsi, jarak ke pemukinan, jarak ke estuari, dan jarak ke sumber benih. Hasil yang diperoleh cukup baik, namun disarankan perlu adanya tambahan data lainnya yang berhubungan dengan kondisi lingkungan fisik dan kualitas air

Model kesesuaian budi daya rumput laut di lokasi penelitian diperoleh dengan menggabungkan tiga submodel yang ada yaitu fisik dan geografi, kualitas air, dan sosial infrastruktur, dengan lebih memberikan penekanan pada submodel fisik dan geografi (Gambar 2). Hal ini dilakukan karena lokasi di tiga teluk menunjukkan bahwa kedalaman perairan merupakan salah satu pembatas untuk budi daya laut (termasuk rumput laut), sedangkan parameter lainnya berada dalam kondisi yang baik dan mendukung. Analisis spasial kesesuaian perairan menunjukkan bahwa ketiga teluk memiliki potensi yang sangat besar untuk dikembangkan yaitu masing-masing dengan kategori sangat sesuai sebesar 159 ha (Teluk Sibigo), 808 ha (Teluk Dalam), dan 684 ha (Teluk Sinabang) (Tabel

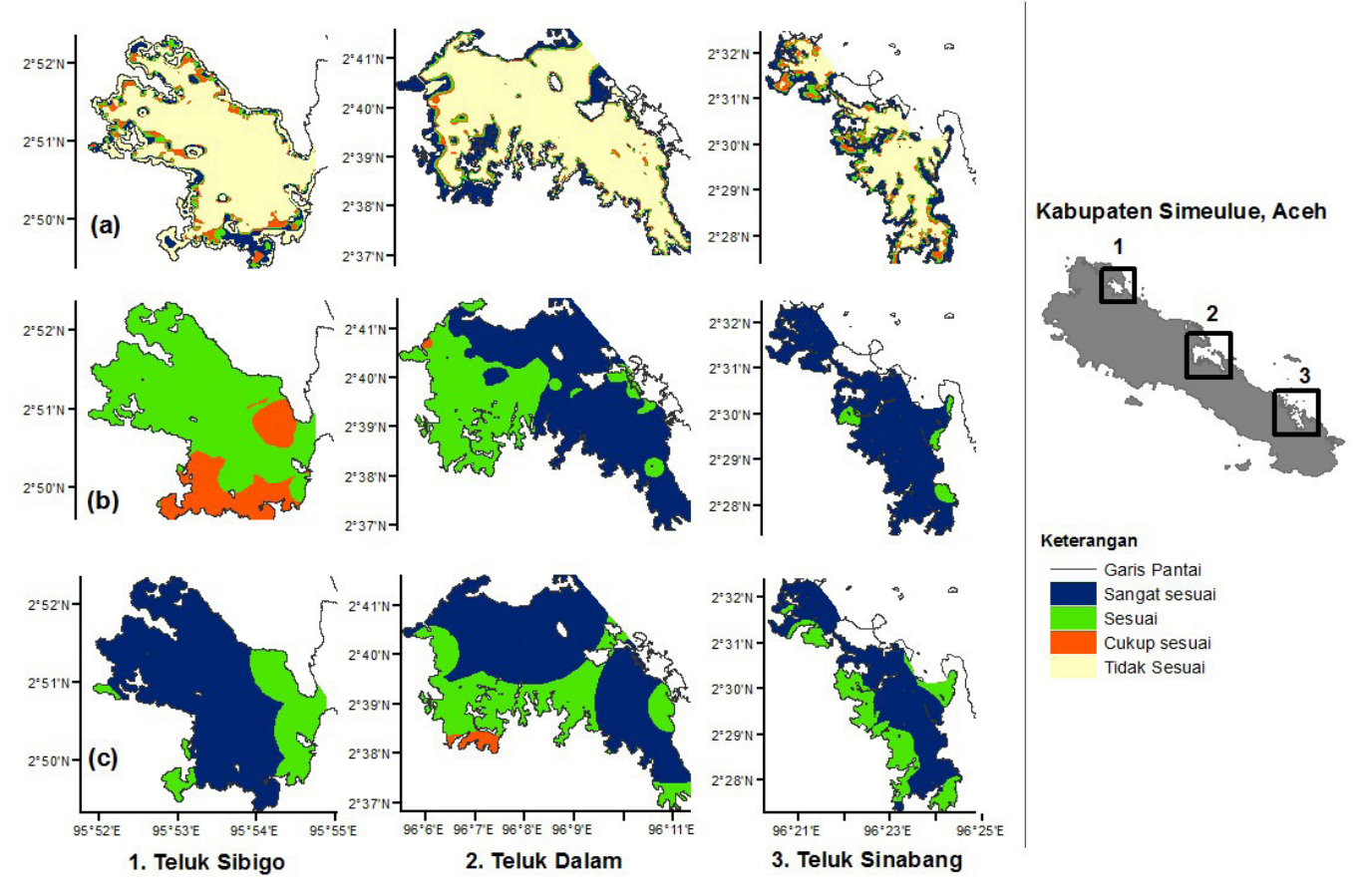

Gambar 4. Kesesuaian budidaya rumput laut berdasarkan submodel fisik dan geografi (a), kualitas perairan (b), dan sosial infrastruktur (c) di Teluk Sibigo, Teluk Dalam, dan Teluk Sinabang Kabupaten Simeulue, Aceh. 


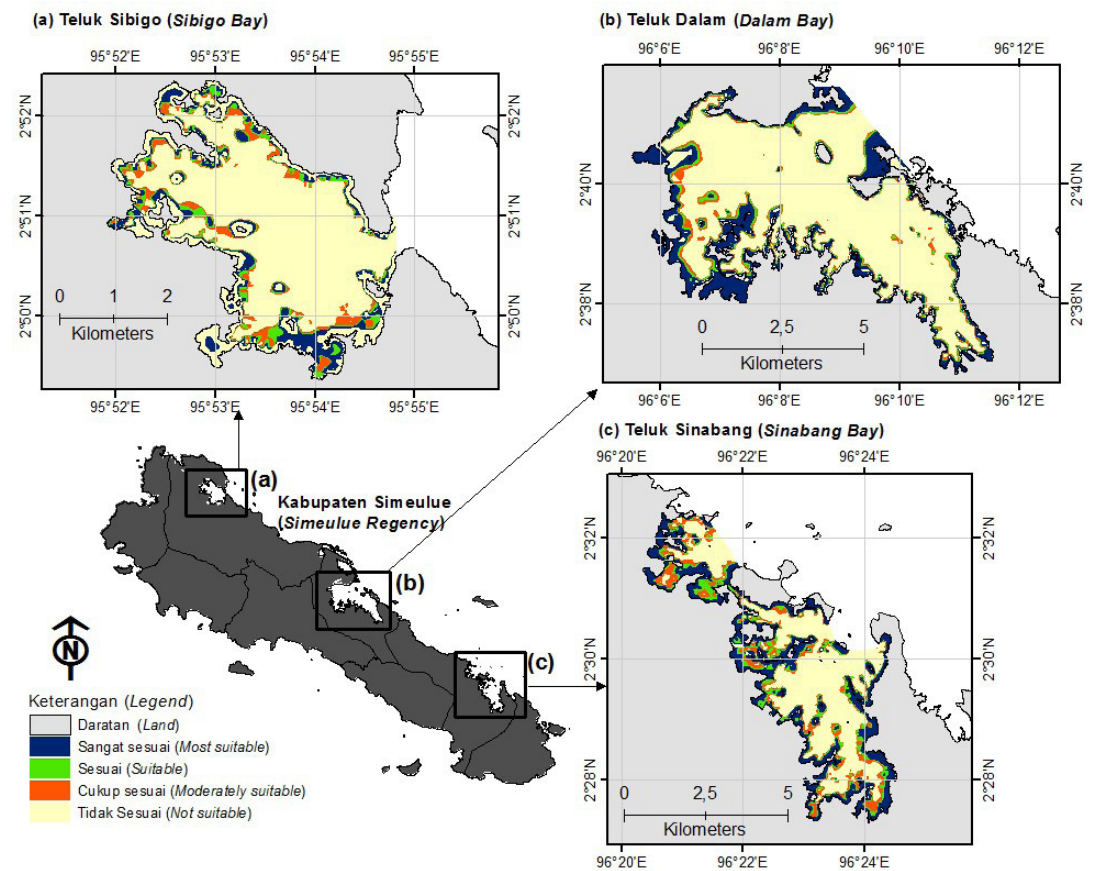

Gambar 5. Peta kesesuaian lahan untuk budidaya rumput laut di Teluk Sibigo, Teluk Dalam, dan Teluk Sinabang Kabupaten Simeulue, Aceh.

2). Daerah dengan kategori sangat sesuai dan sesuai umumnya berada di sekitar pesisir pantai melingkari seluruh kawasan teluk (Gambar 5).

Penelitian ini telah memanfaatkan analisis spasial dengan SIG melalui penggabungan beberapa parameter yang dikelompokkan dalam tiga submodel. SIG dapat membantu dalam melakukan analisis spasial, dan belakangan ini semakin banyak dimanfaatkan untuk perencanaan spasial perikanan budi daya yang meliputi berbagai aspek kajian: kesesuaian lahan, pemantauan aktivitas budi daya dan perairan, serta pemanfaatan lahan (Aguilar-Manjarrez et al., 2010; Ross et al., 2013). Pemilihan parameter dan pengumpulan data juga menjadi salah satu kunci analisis. Pendekatan lain yang dapat digunakan adalah memanfaatkan data penginderaan jauh untuk mengekstrak parameter kualitas air untuk memperoleh model kesesuaian perairan (Liu et al., 2014).

\section{Daya dukung perairan untuk budi daya rumput laut}

Daya dukung merupakan konsep penting untuk manajemen berbasis ekosistem yang membantu menentukan batas atas produksi perikanan budi daya dan batas ekologis, dan penerimaan sosial dari budi daya tanpa menyebabkan perubahan yang tidak dapat diterima dari aspek ekosistem, sosial dan ekonomi (Byron \& Costa- Pierce, 2013). Daya dukung kawasan untuk mempertahankan fungsi ekosistem dapat dihitung dalam berbagai cara dan tergantung pada banyak faktor, sehingga kadang kala pengukurannya menjadi tidak pasti. Dengan keterbatasan tersebut, perkiraan perhitungan daya dukung digunakan sebagai acuan untuk pengelolaan sumberdaya, dan diterapkan secara hati-hati sesuai dengan regulasi dan aturan yang berlaku (Telfor \& Robinson, 2003).

Daya dukung merupakan faktor penting untuk menjaga keberlanjutan kegiatan budi daya rumput laut serta sistem produksi pangan lainnya. Jika kegiatan budi daya rumput laut yang dilakukan melebihi daya dukung perairan, maka budi daya rumput laut tidak dapat berlangsung secara berkelanjutan. Selain itu, kontribusi yang diharapkan positif terhadap lingkungan, terutama penyerapan nutrien dari air akan menjadi tidak efisien (Yuniarsih et al., 2014).

Teknik budi daya rumput laut yang berbeda akan menghasilkan daya dukung lingkungan yang berbeda. Perhitungan daya dukung dalam penelitian ini berdasarkan budi daya rumput laut metode longline dengan ukuran unit $50 \mathrm{~m} \times 50 \mathrm{~m}$. Tabel 3 menyajikan perhitungan daya dukung perairan di lokasi penelitian. Kawasan yang sesuai di lokasi penelitian yaitu 241 ha (Teluk Sibigo), 1.010 ha (Teluk Dalam), dan 915 ha (Teluk Sinabang); memiliki daya dukung untuk pengembangan budi daya rumput laut masing-masing sebanyak 241 unit (Teluk Sibigo), 1.010 unit (Teluk Dalam), dan 915 unit (Teluk Sinabang). Jika produksi per unit budi daya diperoleh sekitar 3 ton rumput laut basah, maka dengan memanfaatkan seluruh kawasan yang ada sesuai dengan daya dukung perairan, total produksi yang dapat dicapai dalam satu siklus musim tanam berkisar antara 723-3.030 ton rumput laut basah (Table 3). 
Table 3.

Perhitungan daya dukung kawasan pegembangan budidaya rumput laut dengan metode longline di Teluk Sibigo, Teluk Dalam, dan Teluk Sinabang KabuaptenSimeulue, Aceh

\begin{tabular}{lllll}
\hline Parameter & Unit & $\begin{array}{l}\text { Teluk } \\
\text { Sibigo }\end{array}$ & $\begin{array}{l}\text { Teluk } \\
\text { Dalam }\end{array}$ & $\begin{array}{l}\text { Teluk } \\
\text { Sinabang }\end{array}$ \\
\hline Kawasan yang sesuai $^{1}$ & ha & 241 & 1010 & 915 \\
Luasan ideal satu unit longline $^{\text {Daya dukung }}$ & ha & 0,49 & 0,49 & 0,49 \\
Produksi total $^{2}$ & unit & 241 & 1.010 & 915 \\
& ton & 723 & 3.030 & 2.744 \\
\hline
\end{tabular}

${ }^{1}$ Kawasan yang sesuai diperoleh dengan menjumlahkan kesesuaian lahan dengan kategori sangat sesuai dan sesuai (lihat Tabel 2). ${ }^{2}$ Produksi total merupakan produksi basah.

Peningkatan aktivitas budi daya laut menjadi perhatian berbagai pihak khususnya masalah dampak yang ditimbulkan terhadap lingkungan perairan (Costa-Pierce, 2008). Pemilihan lokasi yang sesuai untuk budi daya laut merupakan salah satu tahapan awal yang harus dilakukan sehingga dalam pelaksanaannya tidak menimbulkan dampak yang serius terhadap lingkungan sekitarnya. Kegiatan budi daya laut yang berkembang tanpa mempertimbangkan kesesuaian lahan dan daya dukung lingkungan sering berakibat tidak berlangsungnya kegiatan tersebut secara berkelanjutan. Penempatan lokasi yang baik bagi kegiatan budi daya laut akan meminimalkan dampak negatif terhadap lingkungan, meminimalkan terjadinya konflik pemanfaatan lahan antara budi daya laut dengan pengguna lahan lainnya (pariwisata, perhubungan, dan industri), dan memaksimalkan keuntungan secara ekonomis (GESAMP, 2001). Budi daya laut harus dapat terintegrasi dengan rencana tata ruang wilayah pantai, dan perlu mengurangi dampak negatif terhadap pengguna lahan pesisir lainnya di lokasi yang sama, sehingga kegiatan budi daya laut ini dapat berkembang secara terintegrasi dengan penguna lahan lainnya (Stead et al., 2002)

Daya dukung tidak bersifat statis, demikian juga dengan aktivitas budi daya; keduanya adalah bersifat dinamis. Oleh karena itu pendugaan daya dukung harus dilakukan dalam jangka waktu tertentu. Pendekatan yang sangat baik jika kesesuaian dan daya dukung perairan dapat dipadukan untuk mendukung perencanaan spasial kawasan pesisir. Selain itu, melalui data daya dukung dapat membantu memperhitungkan resiko yang ditimbulkan oleh aktivitas budi daya. Kesesuaian (zonasi) dan daya dukung perairan yang dihasilkan dalam penelitian ini menjadi landasan penting mendukung penerapan budi daya perikanan yang berbasis ekosistem (Ecosystem Approach to Aquaculture-EAA; Soto et al., 2008). Melalui EAA, integrasi dari budi daya di dalam ekosistem yang lebih luas bisa mempromosikan pembangunan berkelanjutan, ekuitas, dan ketahanan sistem sosial-ekologi yang saling terkait.

\section{KESIMPULAN}

Kajian kesesuaian perairan dan dipadukan dengan perhitungan daya dukung perairan menjadi data dasar dalam perencanaan spasial kawasan. Hasil pengumpulan data pada musim kemarau (Agustus) di Kabupaten Simeulue yang meliputi Teluk Sibigo, Teluk Dalam, dan Teluk Sinabang menunjukkan potensi yang bervariasi berdasarkan analisis tingkat kesesuaian perairan. Berdasarkan metode budi daya rumput laut dengan sistem longline, Teluk Dalam memiliki potensi yang sangat besar (kategori sangat sesuai sebesar 808 ha dan daya dukung kawasan 494,7 ha dibandingkan dengan dua teluk lainnya (Teluk Sibigo dan Teluk Sinabang). Potensi yang ada tersebut dapat dimanfaatkan secara maksimal sesuai dengan daya dukung kawasan masing-masing teluk.

Strategi yang dapat ditempuh guna mendukung pengembangan rumput laut di lokasi penelitian adalah penyediaan bibit unggul rumput laut, melakukan demplot percontohan budi daya rumput laut dengan melibatkan langsung masyarakat pesisir (kelompok pembudi daya), dan membuka akses pasar. Konektivitas antara potensi lahan yang ada dan strategi pengembangan di lokasi penelitian diharapkan dapat mendukung pengembangan budi daya rumput laut secara berkelanjutan.

\section{PERSANTUNAN}

Penulis mengucapkan terima kasih kepada Dinas Kelautan dan Perikanan Kabupaten Simeulue atas bantuannya selama kegiatan lapangan. Kami mengucapkan terima kasih kepada Rasidi, Kuncoro, Panglima Laut Kabupaten Simeulue, Panglima Laut Teluk Dalam yang telah membantu kelancaran pengumpulan data lapangan. Penelitian ini merupakan bagian dari penelitian Analisa Kebijakan Pengembangan Marikultur Pusat Penelitian dan Pengembangan Perikanan T.A 2015. 


\section{DAFTAR PUSTAKA}

Aguilar-Manjarrez, J., Kapetsky, J.M. \& Soto, D. (2010). The potential of spatial planning tools to support the ecosystem approach to aquaculture.FAO/ Rome. Expert Workshop. 19-21 November 2008, Rome, Italy. FAO Fisheries and Aquaculture Proceedings. No.17. Rome, FAO. 176 hal.

Anonimous. (2015). Pengembangan Kawasan Kelautan dan Perikanan Terintegrasi di Kabupaten Simeuleu. Direktorat Jenderal Kelautan, Pesisir dan Pulau-Pulau Kecil, Kementerian Kelautan dan Perikanan. 152 hal.

Azis, H.Y. (2011). Optimasi Pengelolaan Sumberdaya Rumput Laut di Kabupaten Bantaeng, Provinsi Sulawesi Selatan. Sekolah Pascasarjana, Institut Pertanian Bogor. 163 hal.

Banai-Kashani, R. (1989). A new method for site suitability analysis: the analytic hierarchy process. Environmental Management, 13: 685-693.

[BBL Lombok] Balai Budi daya Laut Lombok. (2012). Petunjuk teknis Budi daya Rumput Laut. Direktorat Jenderal Perikanan Budi daya, Kementerian Kelautan dan Perikanan. 31 hal.

Byron, C.J. \& Costa-Pierce, B.A. (2013). Carrying capacity tools for use in the implementation of an ecosystems approach to aquaculture. In L.G. Ross, T.C. Telfer, L. Falconer, D. Soto \& J. AguilarManjarrez, eds. Site selection and carrying capacities for inland and coastal aquaculture, $\mathrm{pp}$. 87-101. FAO/Institute of Aquaculture, University of Stirling, Expert Workshop, 6-8 December 2010. Stirling, the United Kingdom of Great Britain and Northern Ireland. FAO Fisheries and Aquaculture Proceedings No. 21. Rome, FAO. 282 hal.

Costa-Pierce, B. (2008). An ecosystem approach to marine aquaculture: a global review. In D. Soto, $\mathrm{J}$. Aguilar-Manjarrez and N. Hishamunda (eds). Building an ecosystem approach to aquaculture. FAO Fisheries and Aquaculture Proceedings. No. 14. Rome, FAO. 81-155.

De Sousa, F.E.S., Moura, E.A. \& Soriano, E.M. (2012). Use of geographic information systems (GIS) to identify adequate sites for cultivation of the seaweed Gracilaria birdiae in Rio Grande do Norte, Northeastern Brazil. Revista Brasileira de Farmacognosia Brazilian Journal of Pharmacognosy, 22(4): 868-873.

Effendi, H. (2003). Telaah Kualitas Air Bagi Pengelolaan Sumberdaya dan Lingkungan Perairan. Kanisius.
Yogyakarta. 258 hal.

Erlania, Radiarta, I N. \& Haryadi, J. (2017). Seleksi parameter pembentuk indeks kualitas perairan untuk pengembangan budi daya laut: studi kasus perairan Teluk Sinabang, Aceh. Segara (under review).

Erlania \& Radiarta, I.N. (2014). Management of sustainable seaweed (Kappaphycus alvarezii) aquaculture in the context of climate change mitigation. Indonesian Journal Aquaculture, 9 (1): 65-72.

FAO. (2016). Global Aquaculture Production (online query). <http://www.fao.org/fishery/topic/16140/ en> diunduh tanggal 1 Mei 2016.

GESAMP (IMO/FAO/UNESCO-IOC/WMO/WHO/IAEA/ UN/UNEP Joint group of experts on the scientific aspects of marine environmental Protection), 2001. Planning and management for sustainable coastal aquaculture development. FAO Rep. Stud. GESAMP No. 68.90 hal.

KKP. (2014). Kelautan dan perikanan dalam angka tahun 2014. Pusat Data Statistik dan Informasi. Kementerian Kelautan dan Perikanan. 302 hal.

KLH [Kementerian Lingkungan Hidup]. (2004). Keputusan Menteri Negara Kependudukan dan Lingkungan Hidup No. 51 tahun 2004, tanggal 8 April 2004 tentang baku mutu air laut. Kementerian Lingkungan Hidup. Jakarta. 11 hal.

Liu, Y., Saitoh, S.I., Radiarta, I.N., Isada, T., Hirawake, T., Mizuta, H. \& Yasui, H. (2013). Improvement of an aquaculture site-selection model for Japanese kelp (Saccharina japonica) in southern Hokkaido, Japan: an application for the impacts of climate events. ICES Journal of Marine Science, 70 (7), 1460-1470. doi:10.1093/icesjms/fst108.

Liu, Y., Saitoh, S-I., Radiarta, I.N., Igarashi, H. \& Hirawake, T. (2014). Spatiotemporal variations in suitable areas for Japanese scallopaquaculture in the Dalian coastal area from 2003 to 2012. Aquaculture, 422-423: 172-183.

Malczewski, J. (1999). GIS and mutlicriteria decision analysis. John Wiley \& Sons. New York, 392 hal.

Malczewski, J. (2000). On the use of weighted linear combination method in GIS: common and best practice approach. Transaction in GIS, 4: 5-22.

Mubarak, H., Ilyas, S., Ismail, W., Wahyuni, I.S., Hartati, S.H., Pratiwi, E., Jangkaru, Z. \& Arifuddin, R. 
(1990). Petunjuk Teknis Budi daya Rumput Laut. Badan Litbang Pertanian, Puslitbang Perikanan. IDRC, Infish. 93 hal.

Nath, S.S., Bolte, J.P., Ross, L.G. \& Aguilar-Manjarrez, J. (2000). Applications of geographical information systems (GIS) for spatial decision support in aquaculture. Aquacultural Engineering, 23: 233-278.

Parenrengi, A., Rachmansyah. \& Suryati, E. (2011). Budi daya Rumput Laut Penghasil Karaginan (Karaginofit). Edisi Revisi. Balai Riset Perikanan Budi daya Air Payau, Badan Penelitian dan Pengembangan Kelautan dan Perikanan, Kementerian Kelautan dan Perikanan, Jakarta. 54 hal.

Perera, R.P. (2013). Public Sector Regulatory Systems for Ecosystems Based Management of Aquaculture: a Gap Analysis Tool. NACA, Bangkok, Thailand. 28 hal..

Radiarta, I,N., Saitoh, S-I. \& Miyazono, A. (2008). GIS-based multi-criteria evaluation models for identifying suitable sites for Japanese scallop (Mizuhopecten yessoensis) aquaculture in Funka Bay, southwestern Hokkaido, Japan. Aquaculture, 284: 127-135.

Radiarta, I .N., Saitoh S-I. \& Yasui, H. (2011). Aquaculture site selection for Japanese kelp (Laminaria japonica) in southern Hokkaido, Japan, using satellite remote sensing and GISbased models. ICES Journal of Marine Science, 68: 773-780.

Radiarta, I.N., Erlania. \& Rasidi. (2014). Analisis pola musim tanam rumput laut, Kappaphycus alvarezii melalui pendekatan kesesuaian lahan di Nusa Penida, Bali. Jurnal Riset Akuakultur, 9 (2): 319330.

Ross, L.G., Falconer, L.L., Mendoza, A.C. \& Palacios, C.A.M. (2011). Spatial modelling for freshwater cage location in the Presa Adolfo Mateos Lopez (El Infiernillo), Michoacan, Mexico. Aquaculture Research, 42: 797-807.

Ross, L.G., Telfer, T.C., Falconer, L., Soto, D., AguilarManjarrez, J., eds. (2013). Site selection and carrying capacities for inland and coastal aquaculture. FAO/Institute of Aquaculture, University of Stirling, Expert Workshop, 6-8 December 2010. Stirling, the United Kingdom of Great Britain and Northern Ireland. FAO Fisheries and Aquaculture Proceedings No. 21. Rome, FAO. 46 hal.
Sanchez-Jerez, P., Karakassis, I., Massa, F., Fezzardi, D., Anguilar Manjarrez, J., Soto, D., Chapela,R., Avila, P., Macias, J.C., Tomassetti, P., Marino, G., Borg, J.A., Franicevic,V., Yucel-Gier, G., Fleming, I.A., Biao, X., Nhhala,H., Hamza, H., Forcada, A. \& Dempster,T. (2016). Aquaculture's struggle for space: the need for coastal spatial planning and the potential benefits of allocated zones for aquacultyre (AZAs) to avoid conflict and promote sustainability. Aquaculture Environment Interaction, 8: 41-54.

Schlitzer, R. (2011). Ocean Data View. WWW Page. http://odv.awi.de.

Soto, D., Aguilar-Manjarrez, J. \& Hishamunda, N. (eds). (2008). Building an ecosystem approach to aquaculture. FAO/Universitat de les Illes Balears Expert Workshop. 7-11 May 2007, Palma de Mallorca, Spain. FAO Fisheries and Aquaculture Proceedings. No. 14. Rome, FAO. 221 hal.

Stead, S.M., Burnell, G. \& Goulletquer, P. (2002). Aquaculture and its role in integrated coastal zone management. Aquac. Int. 10: 447-468.

Sulistijo \& Nontji, A. (1995). Potensi lingkungan laut untuk kegiatan budi daya. Sudradjat et al. (penyunting). Prosiding temu usaha pemasyarakatan teknologi keramba jaring apung bagi budi daya laut, Jakarta 12-13 April 1995. Pusat Penelitian dan Pengembangan Perikanan, Badan Litbang Pertanian bekerjasama dengan Forum Komunikasi Penelitian dan Pengembangan Agribisnis. Hal. 54-68.

Telfor, T. \& Robinson, K. (2003). Environmental quality and carrying capacity for aquaculture in Mulroy Bay Co. Donegal. Marine Institute, Marine Environment and Food Safety Services, Parkmore, Galway. Marine Environment and Health Series, No.9. 103 hal.

Tiensongrusmee, B. (1990). Site selection for Eucheuma spp. farming. UNDP/FAO Regional Seafarming Development and Demonstration Project (RAS/90/002). Kasetsart University Campus, Bangkok, Thailand. http://www.fao.org/ docrep/field/003/AB738E/AB738E00.htm\#TOC disadur tanggal 30 November 2010.

Yuniarsih, E., Nirmala, K. \& Radiarta, I.N. (2014). Tingkat penyerapan nitrogen dan fosfor pada budi daya rumput laut berbasis IMTA (integrated multitrophic aquaculture) di Teluk Gerupuk, Lombok Tengah, Nusa Tenggara Barat. Jurnal Riset Akuakultur, 9 (3): 487-501. 